In addition to his teaching, administrative and research interests, Mr. Prince was a keen gardener, numismatist, and photographer. He was also a faithful member of the I.O.O.F. St. George Lodge No. 39 and an active member of iSt. John the Evangelist Anglican Church.

I feel a deep personal loss at his death as he was a close friend of mine from the time I joined the staff in 1962 . With our joint interest in lichens and bryophytes we had much in common.

$\mathrm{Mr}$. Prince is survived by his wife Honor; four sons, John, Henry, Richard, and Theodore; and a sister, Mrs. Elaine Wehmeyer.

Mrs. Prince, in her husband's memory has established The Reg Prince Memorial Prize in Botany to be awarded annually to a student proceeding into the fourth year of a B.Sc. Botany programme at the University of Calgary.

\title{
NOTES ON ERUCA SATIVA, THE PIONEER'S POT-HERB
}

\section{by B. M. Hallworth, The Herbarium, Biology Department, University of Calgary}

Eruca sativa Mill. is a member of the mustard family, Cruciferae. It is a large, $\quad 20-100 \mathrm{~cm}$ high, spreading, rough-hairy annual or biennial, with interesting flowers. These are large, compared with those of other members of the Cruciferae; the petals are 1.5 - 2 $\mathrm{cm}$ long and are pale yellow. They have distinctive violet, sometimes brown, veins. The silique has a welldeveloped beak, and is similar to that found in the genus Brassica. The two genera are closely allied, but Eruca fruits have two rows of seeds in each valve whereas Brassica fruits have only one. Eruca can be distinguished from other yellow-flowered mustards in two ways; it has a fruit with a prominent beak, and the petals have the characteristic vein-markings. One of our related mustards, Erucastrum gallicum, gets is generic name from its resemblance to Eruca.

Eruca sativa is a native plant of the Mediterranean area, and for many years it has been cultivated as a salad plant and vegetable, and for the medicinal oil obtained from its seeds. The species name, sativa, from the Latin word for "sown", reminds us that it is a cultivated plant, and its common name, Rocket Salad, also suggests this. Eruca vesicaria (L.) Cav. is sometimes given as a synonym.

The pioneer settlers in Ontario brought seeds of Eruca from Europe and grew them for use as pot-herbs and in salads. Some plants escaped from cultivation and became weeds. Eruca seeds were also brought from Europe mixed with alfalfa seed (Clarke \& Fletcher, 1909). Farmers from various parts of Ontario sent samples to the Experimental Farm, Ottawa. These came from Preston (1907), Galt (1908), Manitick (1909); East Linton, Wingham, and Laurier (1910) ; and from Melbourne, Markdale, and Palmerston (1911). John Macoun, the "Father of Canadian Botany", collected a plant near Ottawa in 1911. The plants had also spread to the West in alfalfa seed, but there is no reference to them being planted as pot-herbs in that region. There are reports at the Herbarium of the Plant Research Institute, Ottawa, from near Regina (1907), Bradwell (1910), and from Carnduff (1912). There are only two records of it from Alberta, from Olds (1910), and from Lacombe (date uncertain, probably before 1912). There is no record of Eruca sativa in the West after 1912. B. Boivin points out (Boivin, 1968-1969) that in many cases these dates and localities are not substantiated by actual specimens. Eruca sativa is not mentioned in the Flora of Alberta by E. H. Moss, and H. J. Scoggan has excluded it from the Flora of Manitoba because of lack of evidence.

In August, 1969, I found some plants of Eruca sativa growing on waste 

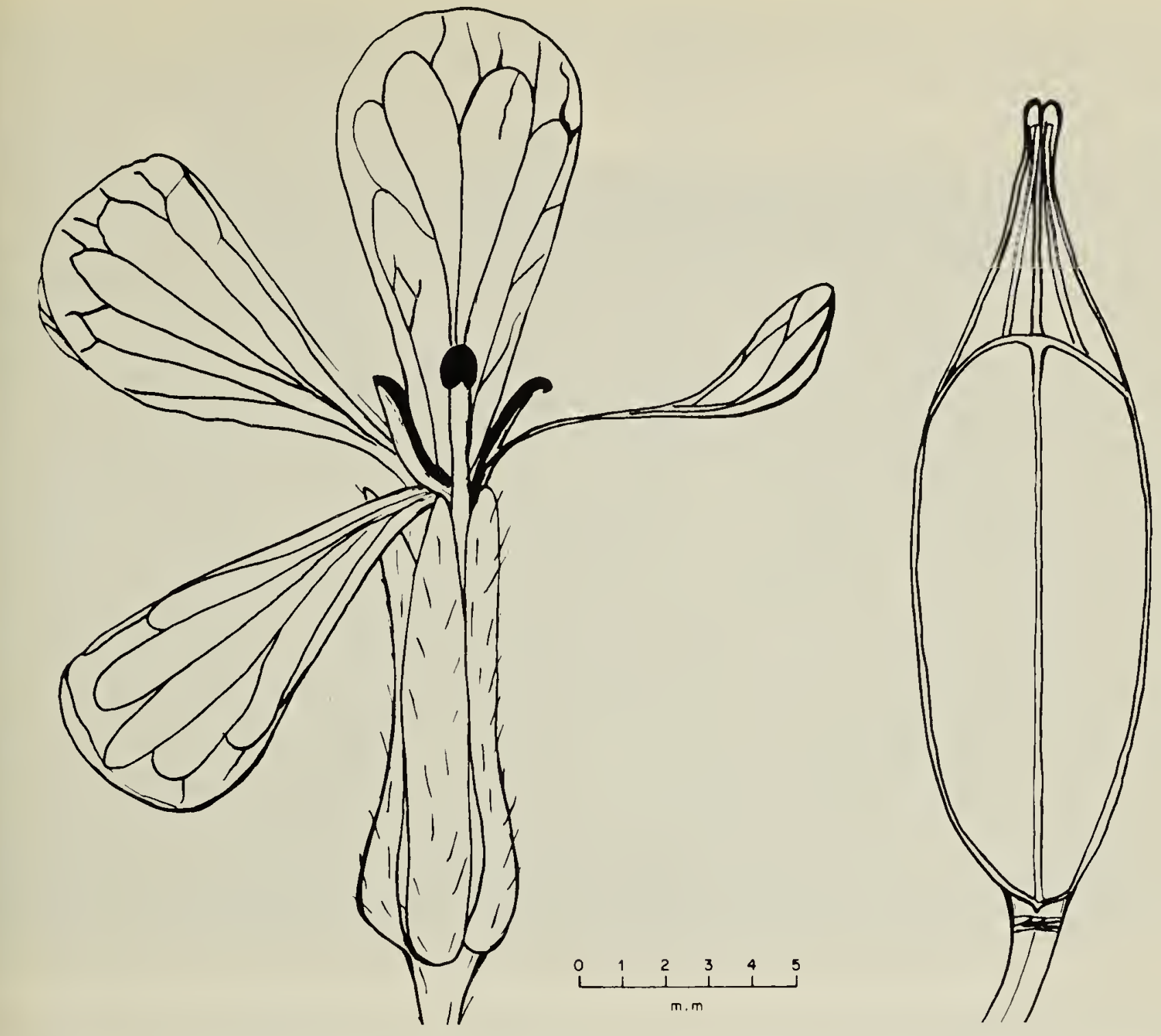

ground close to the University of Calgary campus. One plant was found on a vacant lot, and about six plants were found on land near a house. On enquiry, I found that the house belonged to Italian immigrants, who had come to Calgary from Italy twenty years ago, and had brought seeds of Eruca sativa with them, to grow as a potherb, just as the original settlers in Ontario had done many years ago. They moved two years ago to the present house. The plant is now once again spreading as a weed. It has colonized the nearby piece of waste land (the plants were large and healthy), and it has spread to the vacant lot, about 40 yards away. Unfortunately, a new house has just been built on the lot, and the waste ground is due to be grassed over by the local council, so possible sites of spread are being eliminated. However, there are several rather weedy backlanes nearby, and if the plant can stand up to stiff competition from the plants already there, it will continue to spread.
The determination was verified by J. Mulligan of the Plant Research Institute, Ottawa. Specimens have been deposited in the Herbarium at the University of Calgary (UAC), and in the Herbarium at the Plant Research Institute (DAO), Ottawa.

\section{Acknowledgements}

I would like to acknowledge the assistance given by W. J. Cody, Curator of the Phanerogamic Herbarium, Plant Research Institute, when I was in Ottawa, examining the specimens of Eruca and correspondence from the farmers who sent in samples; also to J. Mulligan who verified the determination; and to C. D. Bird, Biology Department, University of Calgary, for suggestions regarding the manuscript.

\section{LITERATURE CITED}

Boivin, B. 1968-1969. Flora of the Prairie Provinces. Part II. Phytologia vol. 16-18.

Clarke, G. and J. Fletcher. 1909. Farm weeds of Canada. 2nd edition. Can. Dept. Agr., Ottawa.

Moss, E. H. 1959. Flora of Alberta. University of Toronto Press, Toronto.

Scoggan, H. J. 1957. Flora of Manitoba. Nat. Museum Canada, Bull. 140. 